\title{
STUDI ALKITAB TERHADAP SUNAT \\ DALAM ROMA 2:25-29; 3:1 \\ DAN IMPLIKASINYA BAGI KEHIDUPAN KRISTEN MASA KINI
}

\author{
Brian Marpay \\ sttjaffraymakassar@yahoo.co.id \\ Simon Alexander Tarigan \\ Tarigan_simon@yahoo.com
}

\begin{abstract}
ABSTRAK
Dalam penulisan ini ada beberapa tujuan yang ditetapkan dan yang ingin dicapai serta merupakan dasar materi ini yaitu: Pertama, untuk menggali pandangan Rasul Paulus tentang sunat dalam Roma 2:25-29; 3:1. Kedua, untuk menjawab implikasi kebenaran sunat bagi kehidupan Kristen masa kini menurut teologi Perjanjian Baru.

Adapun metode yang dipakai dalam penulisan ini: Pertama, penelitian kualitatif atau mencari makna sunat berdasarkan Surat Roma 2:25-29; 3:1. Sistematika penulisannya ialah, literatur tentang surat Roma, literatur tentang sunat, teologi Rasul Paulus. Kedua, eksegesis hermeneutika tentang sunat berdasarkan Roma 2:25-29; 3:1. Teknik pengumpulan data ialah inventarisasi, evaluasi kritis. Teknik analisis data ialah interpretasi, dan komparasi serta menulis hasilnya secara deskriptif.

Berdasarkan uraian tentang studi Alkitab terhadap sunat dalam Roma 2:25-29; 3:1 dan implikasi bagi kehidupan Kristen masa kini, maka dengan ini penulis mengemukakan secara praktis beberapa hasil sebagai kesimpulanya: Pertama, sunat lahiriah tidak berfaedah ketika seseorang masih hidup dalam dosa dan tidak menaati Firman Tuhan. Kedua, sunat lahiriah hanya sebatas simbolis, sedangkan sunat hati sangat perlu dalam hidup kekristenan. Ketiga, Sunat yang dilakukan secara lahiriah (sarx) yakni pada tubuh atau daging hanya sebatas aturan atau tradisi. Keempat, sunat hati ialah sebuah situasi di mana seseorang yang sebelumnya hidup dalam dosa namun atas dasar kesadaran akan dosa atau pelanggaran, mempersilahkan Allah untuk masuk dalam hatinya, membersihkan hidupnya dari segala dosa (mengerat/menyunatkan hatinya) bagi Allah sehingga dapat menjalin intimasi dengan Allah yang kudus. Kelima, sunat sangat bermanfaat bagi kesehatan. Tuhan memakai para tenaga medis untuk menyingkapkan kebenaran. Allah tidak merancang sunat sebagai alasan medis, tetapi sunat sangat bermanfaat secara medis.
\end{abstract}

Kata Kunci: Studi Alkitab, Sunat, dan Kehidupan Kristen Masa Kini 


\section{PENDAHULUAN}

\section{Latar Belakang Masalah}

Seorang yang mengasihi Allah tentunya akan menaati atau menuruti perintah dan Firman-Nya. Salah satu perintah Allah ialah tentang sunat, keadaan inilah yang dibuktikan oleh Abraham. Dalam Perjanjian Lama, Abraham menunjukkan ketaatan-Nya kepada Allah dalam hal sunat, Kejadian 17:1-27. Walaupun dalam Perjanjian Baru sunat didepenulisankan oleh Paulus sebagai suatu bentuk penyucian hati atau hidup, di mana "kita harus mengerat kulit khatan hati kita untuk menjalin intimasi dengan Allah yang Kudus".

Hal penting lainnya di mana Allah menjadikan sunat sebagai Lambang Perjanjian antara Allah dengan Abraham, sunat merupakan tanda kepunyaan Tuhan secara fisikal yang telah dimeteraikan Allah dengan penumpahan darah. Sebab diluar bangsa Israel sunat tidak memiliki arti apa-apa, "Haruslah dikerat kulit khatanmu dan itulah akan menjadi tanda perjanjian antara Aku dan kamu” (Kej 17:11).

Perjanjian Baru juga membahas sunat. Rasul Paulus sebagai pelopor dari "sunat hati", mengidentifikasikan sunat dalam Perjanjian Baru sebagai suatu bentuk penyucian hati, penanggalan akan tubuh (sifat) yang berdosa dan mau hidup dalam pertobatan, yakni meninggalkan tabiat lama (dosa) dan mau menyunatkan hatinya bagi Kristus.

Dewasa ini pandangan banyak orang tentang sunat telah disalah artikan. Seiring dengan berkembangnya sains dan teknologi, bahkan pandangan dari para pemikir teolog menjadikan sunat sebagai salah satu konsep kebenaran yang tak perlu dibahas. Mengapa? Sebab sunat merupakan sebuah ketetapan yang sudah usang dan hal tersebut berlaku hanya pada zaman Perjanjian Lama atau Taurat saja, sedangkan zaman sudah berubah, "sunat dan tidak sunat" tidak ada pengaruhnya dalam iman kristiani. Keadaan inilah yang sering penulis jumpai dalam kehidupan kekristenan tanpa memahami makna sunat dengan baik. Sebagai orangorang yang percaya kepada Tuhan, tentunya kita juga perlu memiliki pengetahuan yang benar tentang kebenaran-kebenaran yang Alkitabiah termasuk didalamnya pengetahuan tentang sunat.

Jika dilihat dari segi medis, sunat memiliki banyak keuntungan bagi seorang pria dewasa, baik kepada dirinya maupun pasangannya. Ilmu kedokteran menemukan banyak keuntungan dari sunat. Ada begitu banyak riset yang dilakukan baik di dalam maupun di luar negeri yang menunjukan keuntungan dari sunat, seperti pencegahan penyakit, alasan kebersihan dan

\footnotetext{
${ }^{1}$ W. Steven Chirstian, Kulit Khatan, (Jogyakarta: Andi 2009) 77. 
kesehatan seperti; dalam lipatan kulup ujung penis tersimpan kotorankotoran (smegma), yang bisa menjadi pencetus kanker, jika tidak dibersihkan, dan masih banyak lagi manfaat sunat.

Sunat merupakan kebenaran Firman Tuhan yang perlu dimengerti dan dipahami oleh setiap orang percaya, baik sunat lahiriah maupun sunat secara batiniah yang dibahas Rasul Paulus dalam Perjanjian Baru. Sunat merupakan kebenaran Firman Tuhan yang Alkitabiah. Itu sebabnya penulis tertarik untuk membahas pokok masalah ini.

Penulis menjumpai bahwa ada begitu banyak orang kristen yang menganggap sunat sebagai sebuah kebodohan yang tak perlu dibahas dan didiskusikan, padahal sunat sebagai sebuah kebenaran yang Ilmiah dan Alkitabiah. Oleh sebab itu penulis, ingin mendepenulisankan sunat dari segi kekristenan atau iman kristen, yaitu pandangan Rasul Paulus terhadap sunat. Sebab masih banyak orang kristen yang belum memahami dengan benar konsep tersebut.

Kenyataan tersebut dapat diketahui bahwa dewasa ini banyak orang Kristen kurang bahkan tidak memahami dengan benar kebenaran mengenai sunat. Sebagian orang lagi memahami sunat dari segi lahiriah saja. Padahal sunat baik secara lahiriah maupun rohaniah sangat ditekan oleh kebenaran Firman Tuhan.

Beberapa orang yang telah penulis wawancarai mengenai sunat, jawaban yang diberikan hampir sama, yaitu lebih kepada sunat secara lahiriah saja." ${ }^{2}$ Selain itu, penulis juga mengadakan wawancara dengan beberapa kaum awam dari kalangan Kristen mengenai arti dan makna sunat, ternyata jawaban yang diberikan pun hampir sama yakni mereka tidak tahu makna sunat secara Alkitabiah."”

Kenyataan di atas membuktikan bahwa pemahaman mengenai sunat sangat diperlukan. Pembahasan mengenai sunat menjadi perlu karena pokok tersebut adalah salah satu pengajaran Alkitab, yang penekanannya lebih kepada arti sunat secara rohani. "Bahkan ada juga yang mengatakan bahwa mereka sering mendengar tentang sunat, tetapi tidak mengetahui makna tentang sunat dalam terang Firman Tuhan.."

Dari jawaban yang diberikan oleh responden terhadap pertanyaan yang penulis ajukan ternyata, ada sebagian orang, baik dari kalangan Kristen dan kaum awam yang memiliki latar belakang kristen, sering mendengar tentang sunat, bahkan mereka juga memahami dengan benar sunat secara lahiriah, tetapi mereka tidak memahami makna sunat secara rohaniah dengan baik dan benar. Orientasi mereka, bahwa sunat itu hanya

\footnotetext{
${ }^{2}$ Deki, Wawancara Oleh Penulis, Makassar, Sulawesi Selatan, 5 Mei 2010.

${ }^{3}$ Hendrik, Wawancara Oleh Penulis, Makassar, Sulawesi Selatan, 5 Mei 2010.

${ }^{4}$ Benyamin, Wawancara Oleh Penulis, Makassar, Sulawesi Selatan, 4 Mei 2010.
} 
dilakukan oleh orang-orang Islam atau agama Islam saja. Hal inilah yang sering membuat penulis bertanya-tanya dalam hati, apakah pemahaman mereka tentang pengajaran sunat kurang diajarkan dalam rumah tangga dan dalam pengajaran-pengajaran di gereja?

Rasul Paulus dalam surat kirimannya kepada jemaat di Roma, membahas situasi dan masalah ini, itu sebabnya penulis memilih surat Roma 2:25-29; 3;1 sebagai bahan kajian, sebab di dalamnya terdapat banyak makna rohani dan kajian ilmiah yang berkaitan dengan judul penulisan yang penulis akan bahas.

Bertolak dari penjelasan-penjelasan di atas maka, masih relevankah sunat ketika diterapkan dalam kehidupan kekristenan saat ini? Kondisi di atas tersebut, selanjutnya memotivasi penulis untuk menindaklanjuti dan menggumulinya dalam sebuah karya ilmiah yang berjudul "STUDI ALKITAB TERHADAP SUNAT DALAM ROMA 2:25-29; 3:1 DAN IMPLIKASINYA BAGI KEHIDUPAN KRISTEN MASA KINI"

\section{Pokok Masalah}

Berdasarkan latar belakang di atas, maka yang menjadi pokok masalah dalam penulisan ini adalah: Pertama, bagaimana memahami pandangan Rasul Paulus tentang sunat dalam Roma 2:25-29; 3:1 ? Kedua, bagaimana implikasi kebenaran sunat bagi kehidupan Kristen masa kini menurut teologi Perjanjian Baru.

\section{Tujuan Penulisan}

Dalam penulisan ini ada beberapa tujuan yang ditetapkan dan yang ingin dicapai serta merupakan dasar materi ini yaitu: Pertama, untuk menggali pandangan Rasul Paulus tentang sunat dalam Roma 2:25-29; 3:1. Kedua, untuk menjawab implikasi kebenaran sunat bagi kehidupan Kristen masa kini menurut teologi Perjanjian Baru.

\section{Manfaat Penulisan}

Beberapa manfaat yang di harapkan dari penulisan ini ialah sebagai berikut: Pertama, bagi jemaat selaku pembaca, agar dapat memahami makna sunat dengan benar. Kedua, untuk mahasiswa teologi, bagi pengembangan teologi tentang sunat. Ketiga, salah satu syarat akademik dalam penyelesaian strata satu (Sl), di Sekolah Tinggi Filsafat Theologia Jaffray.

\section{Metode Penelitian}

Adapun metode yang dipakai dalam penulisan ini: Pertama, penelitian kualitatif atau mencari makna sunat berdasarkan Surat Roma 2:25-29; 3:1. 
Sistematika penulisannya ialah, literatur tentang surat Roma, literatur tentang sunat, teologi Rasul Paulus.

Kedua, eksegesis hermeneutika tentang sunat berdasarkan Roma 2:25-29; 3:1. Teknik pengumpulan data ialah inventarisasi, evaluasi kritis. Teknik analisis data ialah interpretasi, dan komparasi serta menulis hasilnya secara deskriptif.

\section{Batasan Penulisan}

Mengingat ruang lingkup pembahasan sunat sangatlah luas, maka penulis membatasi dan memfokuskan penulisan ini menurut pandangan Alkitab, yakni hanya pada Surat Roma 2:25-29; 3:1 berdasarkan pandangan R.A. Jaffray dan van den End.

\section{Studi Alkitab Terhadap Sunat Dalam Roma 2:25-29; 3:1 \\ Literatur Surat Roma}

Surat Roma merupakan surat kiriman Paulus yang sangat istimewa dan tentunya eksklusif dari antara surat-surat yang lain. Sebab di dalam pembahasanya, Rasul Paulus menulis dengan cermat segala hal yang berkaitan dengan jalan menuju keselamatan." ${ }^{5}$ Menurut Martin Luther, seorang pemuka Gereja Injili yang dikutip oleh Dr. R.A. Jaffray pernah berkata bahwa: "Surat Roma adalah satu dari antara kitab-kitab yang terutama dan yang terpenting. Jika seandainya ada orang-orang yang memusuhi agama Kristen, lalu dengan kekuasaan mereka seluruh Alkitab dan surat-surat pengajaran Kristen dibakar habis, kita tidak perlu takut seandainya yang masih tertinggal hanya Injil Yohanes dan Surat Roma. Dengan beralasan kedua kitab itu, Injil Tuhan masih dapat dijalankan."

Alasan pemilihan surat Roma 2:25-29; 3:1 sebagai bahan penelitian dan kajian tentang sunat, sebab di dalam ayat-ayat ini penulis menemukan dua variabel kebenaran yang saling berkaitan dan melengkapi untuk menjadi dasar pengembangan teologi sunat. Bertolak dari statemen dan penjelasan di atas penulis dapat menyimpulkan bahwa Surat Roma memiliki makna teologi yang dalam dan yang mengandung kebenaran yang bernilai tinggi.

\section{Latar Belakang Surat Roma \\ Penulis}

Ada banyak penafsiran dan perdebatan yang menetang identitas dari karya penulisan surat Roma ini. "Para pakar teologi liberal berusaha

\footnotetext{
${ }^{5}$ R.A. Jaffray, Tafsiran Surat Roma (Bandung: Kalam Hidup, 2007), 9 2007), 14

${ }^{6}$ Martin Luther dalam R.A. Jaffray, Tafsiran Surat Roma (Bandung: Kalam Hidup,
} 
menyakinkan pendapat mereka bahwa Rasul Paulus tidak menulis surat Roma, tetapi perdebatan tersebut sudah dapat diselesaikan, dan hampir semua sepakat untuk mengakui Rasul Paulus sebagai penulis surat Roma"'. Jadi berdasarkan Roma 1:1; 1:10-15; 15:22-32 penulis dapat menyimpulkan bahwa Rasul Paulus merupakan penulis Surat Roma, selain itu penulis juga melihat beberapa naskah kitab seperti dalam Kisah Para Rasul 19:21, dimana Rasul Paulus sendiri memiliki kerinduan yang besar untuk mengunjungi Roma, dari beberapa bukti yang ada, menunjukan Rasul Pauluslah merupakan penulis surat Roma.

\section{Garis Besar}

Untuk memahami surat Roma dengan mudah, penulis membuat garis besar atau kerangka dasar dari surat Roma berdasarkan pokok pemikiran William Barclay yang di kombinasikan dengan garis besar Surat Roma menurut Alkitab Penuntun Hidup Berkelimpahan, sebagai berikut: Pertama, pasal 1-8, mengenai masalah kebenaran. Dalam beberapa pasal ini, di dalamnya Paulus membahas beberapa poin penting antara lain membahas kebutuhan mendesak manusia akan kebenaran, penyediaan kebenaran yang mulia dari Allah dan kebenaran berkarya melalui Iman." Kedua, pasal 9-11, mengenai masalah bangsa Yahudi, sebagai umat pilihan Allah. Yang mana dalam beberapa pasal ini, di dalamnya Paulus membahas beberapa poin penting lain seperti kebenaran oleh iman yang berkaitan dengan Israel. Ketiga, pasal 12-15, mengenai masalah kehidupan praktis, seperti penerapan praktis dari kebenaran oleh iman. Keempat, pasal 16, surat pengantar untuk Fede, dan suatu daftar nama orang-orang yang secara khusus Paulus kirim salam sekaligus sebagai penutup dari Surat Kiriman Paulus ini."

\section{Doktrin Penting Surat Roma}

Pengalaman Paulus dan teologi Paulus adalah tak terpisahkan. Pengajaran utama dalam Surat Roma yang merupakan hasil karya Rasul Paulus yaitu lebih menekankan pada pembenaran Allah oleh Iman. "Karena baik orang Yahudi maupun orang bukan Yahudi berada dibawah dosa dan karena itu di bawah murka Allah, tidak ada seorang pun yang dapat dibenarkan di hadapan Allah terlepas dari karunia kebenaran melalui iman kepada Yesus Kristus"10 Jadi hanya iman kepada Yesus saja setiap orang diselamatkan.

\footnotetext{
${ }^{7}$ Dave Hagelberg, Tafsiran Roma dari bahasa Yunani, (Bandung: Kalam Hidup, 2004), 4

${ }^{8}$ Alkitab Penuntun Hidup Berkelimpahan Full Life Study Bible, (Malang: Gandum Mas dan Lembaga Alkitab Indonesia, 2008) 1832

${ }_{9}^{9}$ William Barclay, Pemahaman Alkitab Setiap Hari, Roma, (Kwitan, Jakarta: BPK.Gunung Mulia, 1986), 13

${ }^{10}$ Alkitab Penuntun Hidup Berkelimpahan Full Life Study Bible, (Malang: Gandum Mas dan Lembaga Alkitab Indonesia, 2008) 1833
} 
Dalam Perjanjian Baru juga banyak di temukan pandanganpandangan Paulus yang merumuskan masalah-masalah praktis, salah satunya adalah tentang sunat. Sunat menjadi masalah yang dipertentangkan dalam kepercayaan Yahudi. Beberapa jemaat dalam Perjanjian Baru seperti jemaat; Galatia, Efesus, Filipi, Kolose. Menghadapi problem ini, mengalami kebingungan, dengan kehadiran Paulus di tengahtengah mereka memberikan angin segar terhadap pemahaman iman mereka kepada Kristus. Seperti penjelasan Yesus dalam Matius 5:17, "Janganlah kamu menyangka, bahwa Aku datang untuk meniadakan hukum Taurat atau kitab para nabi. Aku datang bukan untuk meniadakannya, melainkan untuk menggenapinya".

Apa sebenarnya yang Paulus bicarakan dalam Perjanjian Baru tentang sunat? Apakah sunat dalam Perjanjian Lama dengan sunat dalam Perjanjian Baru memiliki kesamaan atau memiliki perbedaan? Penulis akan menjawab kedua pertanyaan ini, dalam uraian dibawah ini.

Hermeneutik Tentang Sunat Dalam Roma 2:25-29; 3:1

Ayat 25 "Sunat memang ada gunanya, jika engkau mentaati hukum Taurat; tetapi jika engkau melanggar hukum Taurat, maka sunatmu tidak ada lagi gunanya". Kata "engkau menaati" dari ayat ini dalam bahasa Yunaninya, menggunakan kata prasses $(\pi \rho \alpha \sigma \sigma \eta \zeta)$ dari kata dasar prasso dibaca pras'-so $(\pi \rho \alpha \sigma \sigma \omega)$ dengan nomor strong G4238. A primary verb; to "practise", that is, perform repeatedly or habitually (thus differing from G4160 which properly refers to a single act); by implication to execute, accomplish, etc.; specifically to collect (dues), fare (personally): - commit, deeds, do, exact, keep, require, use arts." Prasso $(\pi \rho \alpha \sigma \sigma \omega)$ berarti "melakukan, menaati, berpraktek dan bertindak". Analisa dari kata prasses ( $\pi \rho \alpha \sigma \sigma \eta \zeta)$ ini ialah (Verb, Second Person, Singular, Present, Active, Subjunctive)."

Kata kedua "melanggar" dalam bahasa Yunaninya parabates dibaca par$a b$-at'-ace $(\pi \alpha \rho \alpha \beta \alpha \tau \eta \zeta)$ dengan nomor strong G3848. Breaker (perusak), transgress (melewati, melampaui, melanggar)"13 Parabates $(\pi \alpha \rho \alpha \beta \alpha \tau \eta \zeta)$ berarti "pelanggar". Analisa dari kata ini (Noun, Masculine, Singular, Nominative)."14

Kata ketiga "keadaan tidak bersunat" dalam bahasa Yunaninya akrobustia dibaca ak-rob-oos-tee'-ah $(\alpha \kappa \rho o \beta v \sigma \tau \iota \alpha)$ dengan nomor strong

\footnotetext{
${ }^{11}$ e-Sword, Strong s.v. "prasso"

${ }^{12}$ Hasan Sutanto, Perjanjian Baru Interlinear Yunani-Indonesia dan Konkordansi Perjanjian Baru jilid II, (Jakarta:Lembaga Alkitab Indonesia, 2003) jilid II 667

13 e-Sword, Strong s.v. "parabates"

${ }^{14}$ Hasan Sutanto, Perjanjian Baru Interlinear Yunani-Indonesia dan Konkordansi Perjanjian Baru jilid II, (Jakarta:Lembaga Alkitab Indonesia, 2003) jilid II 603
} 
G203. From G206 and probably a modified form of $\pi 0 \sigma \theta \eta$ posthe (the penis or male sexual organ); the prepuce; by implication an uncircumcised (that is, gentile, figuratively unregenerate) state or person: - not circumcised, uncircumcised [with G2192], uncircumcision." 15 akrobustia ( $\alpha \kappa \rho o \beta v \sigma \tau \iota \alpha)$ berarti "keadaan tidak bersunat; orang yang tidak bersunat berarti orang yang bukan Yahudi". Analisa dari kata ini (Noun, Feminine, singular, Nominative)."16 Akrobustia, LAI (Lembaga Alkitab Indonesia) yang berarti "yang tak bersunat", dapat menyandang tiga arti (a) kulup (khitan); (b) keadaan berkulup (tak bersunat); (c) golongan orang yang berkulup (dunia orang kafir).,"

Kata keempat "telah menjadi" dalam bahasa Yunaninya mengunakan

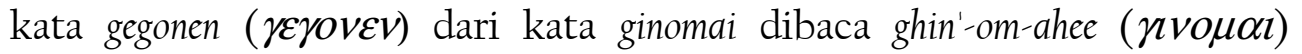
Ddengan nomor strong G1096. A prolonged and middle form of a primary verb; to cause to be ("gen" -erate), that is, (reflexively) to become (come into being), used with great latitude (literally, figuratively, intensively, etc.): - arise be assembled, be (come, fall, -have self), be brought (to pass), (be) come (to pass), continue, be divided, be done, draw, be ended, fall, be finished, follow, be found, be fulfilled, + God forbid, grow, happen, have, be kept, be made, be married, be ordained to be, partake, pass, be performed, be published, require, seem, be showed, $X$ soon as it was, sound, be taken, be turned, use, wax, will, would, be wrought."18 Ginomai ( $r v o \mu \alpha l$ ) berarti "ada, menjadi, berhasil". Analisa dari kata gegonen ( $\mathcal{E}$ \&ovev) ini ialah (Verb, third person, Singular, Perfect, Active, Indicative)."

Menurut R.A. Jaffray, mengenai Roma 2:25 ini, "Paulus hendak menegaskan nilai sunat yang dilakukan atas dasar adat nenek moyang, yang bertentangan dengan hukum Allah. Oleh sebab itu, sekalipun orang itu bersunat, sebenarnya orang itu sama dengan orang yang tidak bersunat. Orang seperti itu tidak berbeda dengan orang yang belum percaya.. ${ }^{20}$

Sedangkan menurut van den End pengertian ayat 25 ini, sebagai jawaban Paulus atas pandangan-pandangan yang sedang berkembang saat itu. Paulus mengakui sunat memang ada gunanya, halnya seperti hukum Taurat sendiri. Kehadiran sunat sangat berguna tatkala bangsa Israel mau menaati hukum Taurat. Sunat sebagai tanda perjanjian dan melalui sunat

\footnotetext{
15 e-Sword, Strong s.v. "akrobustia"

${ }^{16}$ Hasan Sutanto, Perjanjian Baru Interlinear Yunani-Indonesia dan Konkordansi Perjanjian Baru jilid II, (Jakarta:Lembaga Alkitab Indonesia, 2003) jilid II 42

${ }^{17}$ Th. Van den End, Tafsiran Alkitab Surat Roma (Jakarta: BPK.Gunung Mulia, 1995) 120

${ }^{18}$ e-Sword, Strong s.v. "ginomai"

${ }^{19}$ Hasan Sutanto, Perjanjian Baru Interlinear Yunani-Indonesia dan Konkordansi Perjanjian Baru jilid II, (Jakarta:Lembaga Alkitab Indonesia, 2003) jilid II 166

${ }^{20}$ R.A. Jaffray, Tafsiran Surat Roma (Bandung: Kalam Hidup, 2007) 46
} 
inilah janji-janji Allah diteguhkan. Manusia diharapkan dapat memenuhi syarat-syarat Perjanjian tersebut. Tetapi saat syarat-syarat tersebut tidak dipenuhi, maka sunatmu tidak ada lagi gunanya. Keadaan ini memberikan sebuah gambaran bahwa secara harfiah sunatmu berubah menjadi keadaan tidak bersunat." 21

Sunat berfungsi saat seseorang menaati, melakukan, atau mempraktekkan (prasso/ $\pi \rho \alpha \sigma \sigma \omega)$ hukum Taurat. Namun sunat menjadi tidak bermakna saat orang tersebut melanggar ( $\pi \alpha \rho \alpha \beta \alpha \tau \eta \zeta$ "pelanggar") hukum Taurat. Apa yang dijelaskan Paulus dalam ayat ini memperlihatkan sikap seriusnya dalam menanggapi pandangan-pandangan orang Yahudi yang hanya mempersoalkan masalah kewajiban keyahudian saja. Menurut Paulus:

Kata pelanggar dipakai juga dalam Yakobus 2:9, di mana orang yang berdosa disebut "pelanggar" hukum Taurat. Dalam ayat ini Paulus menegaskan bahwa bagi pelanggar hukum Taurat, sunat mereka sudah menjadi tidak bersunat. Di sini ia berbicara keras karena justru istilah tidak bersunat dipakai untuk menceritakan orang bukan Yahudi! Dengan kata lain, ia berkata, "kalau kamu yang bersunat berdosa, maka kamu menjadi bukan Yahudi! ${ }^{22}$.

Jadi kata $\pi \alpha \rho \alpha \beta \alpha \tau \eta \zeta$ yang yang mengandung arti "pelanggar/melanggar" akan berkaitan dengan kata

" $\alpha \kappa \pi o \beta v \sigma \tau \iota \alpha \gamma \varepsilon \gamma o v \varepsilon v$ " yang berarti "telah menjadi keadaan tidak bersunat". Itu artinya sunatmu tidak ada lagi gunanya. Kalimat sunatmu berubah menjadi keadaan tidak bersunat, "berarti: kamu menjadi sama seperti orang yang tidak bersunat, hatimu sama saja keadaannya dengan hati dia, yaitu dikuasai dosa." 23

Ayat 26, "Jadi jika orang yang tak bersunat memperhatikan tuntutantuntutan hukum Taurat, tidakkah ia dianggap sama dengan orang yang telah disunat?" Kata "memperhatikan"dari ayat ini dalam bahasa Yunaninya menggunakan kata phulasse dari kata phulasso dibaca foo-las'-so $(\phi v \lambda \alpha \sigma \sigma \omega)$ dengan nomor strong G5442. Probably from G5443 through the idea of isolation; to watch, that is, be on guard (literally or figuratively); by implication to preserve. obey, avoid: - beware, keep (self), observe, save. Compare G5083. ${ }^{24}$ Phulasso

\footnotetext{
${ }^{21}$ Th. Van den End, Tafsiran Alkitab Surat Roma (Jakarta: BPK.Gunung Mulia, 1995) $118-119$

${ }^{22}$ Dave Hagelberg, Tafsiran Roma dari bahasa Yunani, (Bandung: Kalam Hidup, 2004),53-54

${ }^{23}$ Th. Van den End, Tafsiran Alkitab Surat Roma (Jakarta: BPK.Gunung Mulia, 1995) 119

24 e-Sword, Strong s.v "phulasso"
} 
$(\phi v \lambda \alpha \sigma \sigma \omega)$ berarti "melakukan penjagaan, menjaga, mematuhi, berjagajaga". Analisa dari kata phulasse ini ialah (Verb, third person, Singular, Present, Aktive, Subjunctive)"25

Kata kedua dari ayat ini, "dianggap" dalam bahasa Yunaninya menggunakan kata logisthesetai ( $\lambda$ on $\sigma \theta \eta \sigma \varepsilon \tau \alpha l)$ dari kata logizomai dibaca log-id'-zom-ahee ( $\lambda$ on $\zeta o \mu \alpha t$ ) dengan nomor strong G3049. Middle voice from G3056; to take an inventory, that is, estimate (literally or figuratively):- conclude, (ac) count (of), + despise, esteem, impute, lay, number, reason, reckon, suppose, think (on)." ${ }^{26}$ Logizomai ( $\lambda$ on $\zeta o \mu \alpha$ ) berarti "memperhitungkan, menganggap, mengira, berniat, menyadari, mempertimbangkan". Analisa dari kata logisthesetai ( $\lambda \circ \gamma \sigma \theta \eta \sigma \varepsilon \tau \alpha l)$ ini ialah (Verb, third person, Singular, Future, Passive, Indicative). ${ }^{.27}$

Menurut R.A. Jaffray dalam ayat 26 ini, Paulus sebagai Rasul bagi bangsa di luar Yahudi mengajukan pembelaannya bahwa seseorang yang belum percaya (yang tidak bersunat), tetapi melakukan Hukum Taurat, maka orang itupun atau seolah-olah bersunat karena ia berkenan kepada Allah. Menurut R.A. Jaffray keadaan dan pengalaman yang dialami orangorang percaya saat ini dimana walaupun sesungguhnya Baptisan dan Perjamuan Kudus itu perlu dan penting, tetapi saat seorang bertobat dengan sungguh dan bersandar pada Kristus karena Imannya, maka orang tersebut dapat dipastikan diperhitungkan ke dalam umat yang akan di selamatkan" 28

Selanjutnya menurut van den End dalam Ayat 26, jika orang yang tidak bersunat memenuhi tuntutan-tuntutan hukum Taurat, ia akan dianggap (Allah) sebagai orang bersunat. Dengan pengertian, bahwa ia akan diterima kedalam perjanjian Tuhan dengan umat-Nya, dan orang tersebut berhak mendapatkan bagian dalam berkat serta janji-janji yang terkandung dalam perjanjian itu. Kata "memperhatikan" berarti bahwa orang tak bersunat (bukan Yahudi) itu tidaklah memenuhi hukum Taurat dengan ketaatan ala kadarnya, tetapi dengan secermat-cermatnya. ${ }^{29}$

Menurut van den End, orang Yahudi tidak dapat menerima kenyataan yang terjadi. Menurutnya, orang yang tidak bersunat dapat dianggap

\footnotetext{
${ }^{25}$ Hasan Sutanto, Perjanjian Baru Interlinear Yunani-Indonesia dan Konkordansi Perjanjian Baru jilid II, (Jakarta:Lembaga Alkitab Indonesia, 2003) jilid II 801

${ }^{26}$ e-Sword, Strong s.v "logizomai"

${ }^{27}$ Hasan Sutanto, Perjanjian Baru Interlinear Yunani-Indonesia dan Konkordansi Perjanjian Baru jilid II, (Jakarta:Lembaga Alkitab Indonesia, 2003) jilid II 488

${ }^{28}$ R.A. Jaffray, Tafsiran Surat Roma (Bandung: Kalam Hidup, 2007) 46

${ }^{29}$ Th. Van den End, Tafsiran Alkitab Surat Roma (Jakarta: BPK.Gunung Mulia, 1995) 120
} 
sebagai orang bersunat dan di sejajarkan dengan mereka yang merupakan penerima janji tersebut. Keadaan tersebut tidak mungkin diterima seorang Yahudi, sebab dengan demikian secara asasi garis pemisah antara bangsa Yahudi dan bangsa-bangsa lain sudah dibatalkan." ${ }^{30}$ Dalam Efesus 2:14 "Karena Dialah damai sejahtera kita, yang telah mempersatukan kedua pihak dan yang telah merubuhkan tembok pemisah, yaitu perseteruan"

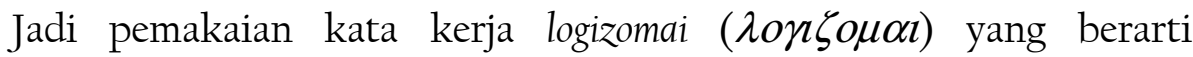
"dianggap" menandakan atau menunjukan keadaan orang yang tak bersunat, Paulus beranggapan bahwa orang-orang seperti ini sebagai orang yang bersunat berdasarkan anugrah Allah. Mereka dapat "memperhatikan" (phulasso/ $\phi v \lambda \alpha \sigma \sigma \omega)$ semua tuntutan-tuntutan hukum Taurat dengan ketaatan mereka di hadapan Tuhan. Maka orang yang tak bersunat tersebut "seolah-olah" bersunat atau disamakan dengan orang yang bersunat (orang Yahudi) sebab ia berkenan di hadapan Allah dengan segala tindakan ketaatannya terhadap hukum Taurat. Ia berhak menerima esensi dari berkat serta janji-janji yang terkandung dari perjanjian tersebut.

Ayat 27, "Jika demikian, maka orang yang tak bersunat, tetapi yang melakukan hukum Taurat, akan menghakimi kamu yang mempunyai hukum tertulis dan sunat, tetapi yang melanggar hukum Taurat". Pertama, kata "akan menghakimi" dalam bahasa Yunaninya krinei ( $\kappa \rho \imath \boldsymbol{l} \varepsilon l)$ dari kata dasar krino dibaca kree'-no ( $\kappa \rho \imath v \omega)$ dengan nomor strong G2919. Properly to distinguish, that is, decide (mentally or judicially); by implication to try, condemn, punish: - avenge, conclude, condemn, damn, decree, determine, esteem, judge, go to (sue at the) law, ordain, call in question, sentence to, think."3l Krino $(\kappa \rho l v \omega)$ berarti "menghakimi, menghukum, berlaku seperti hakim, mencari keadilan." Analisa dari kata krinei ( $\kappa \rho \imath v \varepsilon l)$ ini ialah (Verb, third person, singular, Future, Active, Indicative). ${ }^{32}$

Kata kedua, "hukum tertulis" dalam bahasa Yunaninya grammatos

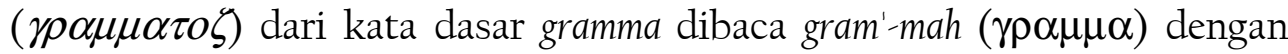
nomor strong Gl121. From Gl125; a writing, that is, a letter, note, epistle, book, etc.; plural learning: - bill, learning, letter, scripture, writing, written." ${ }^{33}$ Gramma

\footnotetext{
${ }^{30}$ Ibid 121

31 e-Sword, Strong s.v "krino"

${ }^{32}$ Hasan Sutanto, Perjanjian Baru Interlinear Yunani-Indonesia dan Konkordansi Perjanjian Baru jilid II, (Jakarta:Lembaga Alkitab Indonesia, 2003) jilid II 463

33 e-Sword, Strong s.v "gramma"
} 
$(\gamma \rho \propto \mu \mu \alpha)$ berarti "huruf, tulisan, kitab, ilmu". Analisa dari kata grammatos ( $\rho \alpha \mu \mu \alpha \tau о \zeta)$ ini ialah (Noun, neuter, Singgular, Genetive)."34

Dari ayat 27 ini menurut R.A. Jaffray bahwa, Paulus hendak menegaskan sebuah prinsip kebenaran yaitu tanda sunat tidaklah penting kalau tidak disertai perbuatan. Sebab orang yang bersunat yang memiliki hukum Taurat sebagai hukum yang tertulis pun kadangkala melangar hukum tersebut. Sebaliknya mereka yang tidak bersunat jika kelakuannya sesuai dengan Hukum Taurat, tetapi kesalehan mereka melebihi orang yang bersunat. Dengan demikian, orang yang tak bersunat, tetapi benar melakukan semua Hukum Taurat, seolah-olah akan menghakimi mereka yang bersunat, tetapi kelakuannya buruk dan tidak senonoh. Tidaklah orang yang bersunat itu dipermalukan bersama-sama dengan sunatnya." 35

Sebaliknya menurut van den End dalam Ayat 27 yang bertolak dari pernyataan Paulus maka: "Ayat ini meneruskan dan mempertajam apa yang telah dikatakan dalam kedua ayat yang terdahulu. (25) Orang Yahudi yang tidak melakukan hukum Taurat statusnya seperti orang yang tidak bersunat. (26) Orang tak bersunat yang melakukan hukum Taurat sama statusnya dengan orang Yahudi. (27) Dalam hukuman terakhir, orang kafir yang demikian malah akan menjadi pengadu orang Yahudi yang tidak melakukan hukum Taurat." 36

Orang yang demikian akan menghakimi kamu. Agaknya yang dimaksud bukan seakan-akan mereka oleh Allah akan diangkat menjadi hakim, melainkan bahwa kesaksian mereka akan memberatkan hukuman atas orang-orang Yahudi yang tidak melakukan hukum Taurat. Gagasan yang sama kita temukan dalam Matius 12:41-42. "Siapakah orang Yahudi yang akan "dihakimi" oleh orang bukan Yahudi? Orang Yahudi yang telah melanggar hukum Taurat, meskipun ia memiliki hukum Taurat dan sunat. Bukan tidak mungkin bahwa "hukum tertulis" itu sendiri menjadi penyebab pelanggaran. Bukan tidak mungkin bahwa orang yang mengandalkan hukum itu memang harus menjadi pelanggar ${ }^{37}$.

Menurut Paulus bahwa orang yang tak bersunat "akrobustia" $(\alpha \kappa \rho o \beta v \sigma \tau \imath \alpha)$ "akan menghakimi" krinei $(\kappa \rho \imath v \varepsilon l)$ kamu. Kata krinei ( $\kappa \rho \imath v \varepsilon l$ ) ini memiliki makna yang cukup dalam, menunjukan keadaan yang akan terjadi di masa mendatang, dimana orang non Yahudi atau yang tak

\footnotetext{
${ }^{34}$ Hasan Sutanto, Perjanjian Baru Interlinear Yunani-Indonesia dan Konkordansi Perjanjian Baru jilid II, (Jakarta:Lembaga Alkitab Indonesia, 2003) jilid II 172

${ }^{35}$ R.A. Jaffray, Tafsiran Surat Roma (Bandung: Kalam Hidup, 2007) 47

${ }^{36}$ Th. Van den End, Tafsiran Alkitab Surat Roma (Jakarta: BPK.Gunung Mulia, 1995) 121

${ }^{37}$ Ibid $122-123$
} 
bersunat "akrobustia ( $\alpha \kappa \rho o \beta v \sigma \tau \iota \alpha)$ " diberikan hak untuk menghukum, bahkan berlaku layaknya seorang hakim dalam mencari keadilan untuk menghakimi kamu yang mempunyai "hukum tertulis" grammatos ( $\rho \alpha \mu \mu \alpha \tau о \zeta)$ tetapi tidak menaatinya bahkan melanggar hukum Taurat. "Agaknya yang dimaksud bukan seakan-akan mereka oleh Allah akan diangkat menjadi hakim, melainkan bahwa kesaksian mereka akan memberatkan hukuman atas orang-orang Yahudi yang tidak melakukan hukum Taurat." 38

Jadi menurut penulis bahwa Paulus ingin mendepenulisankan opininya tentang orang kafir atau yang tak bersunat "akrobustia $(\alpha \kappa \rho o \beta v \sigma \tau \iota)$ ), yang mana mereka melakukan ketentuan-ketentuan hukum Taurat. Menurut Paulus, meskipun mereka tak bersunat, tetapi melakukan hukum Taurat dan menjalankan ketetapan-ketetapan Taurat maka mereka bisa saja menghakimi orang Yahudi yang notabene bersunat, namun sedikitpun tidak mengindahkan dan menghidupi Taurat tersebut.

Ayat 28-29 "Sebab yang disebut Yahudi bukanlah orang yang lahiriah Yahudi, dan yang disebut sunat, bukanlah sunat yang dilangsungkan secara lahiriah. Tetapi orang Yahudi sejati ialah dia yang tidak nampak keyahudiannya dan sunat ialah sunat di dalam hati, secara rohani, bukan secara hurufiah. Maka pujian baginya datang bukan dari manusia, melainkan dari Allah". Penulis menggabungkan kedua ayat ini untuk dieksigesis, sebab memiliki keterkaitan dan sealur.

Kata pertama, "yang lahiriah" dalam bahasa Yunaninya phanero $(\phi \alpha v \varepsilon \rho \omega)$ dari kata phaneros dibaca fan-er-os' ( $\phi \alpha v \varepsilon \rho o \zeta)$ dengan nomor strong G5318. From G5316; shining, that is, apparent (literally or figuratively); neuter (as adverb) publicly, externally: - abroad, + appear, known, manifest, open [+ ly], outward ([+-ly])."39 Phaneros ( $\phi \alpha v \varepsilon \rho o \zeta)$ berarti "nyata, yang kelihatan, yang terkenal, yang diluar". Analisa dari kata phanero $(\phi \alpha v \varepsilon \rho \omega)$ ini ialah (Adjective, Neuter, Singular, Dative, no degree)."40 "Yang nampak" atau "yang lahiriah" mengacu pada lembaga-lembaga kelihatan yang telah ditetapkan menjadi tanda perjanjian antara Allah dengan umat-Nya. Tanda-tanda itu adalah hukum Taurat dan sunat."

Kata kedua, "secara lahiriah" Lembaga Alkitab Indonesia (LAI) menggunakan kata ini. Lebih tepat menggunakan kata "di dalam daging"

\footnotetext{
${ }^{38}$ Ibid 122

${ }^{39}$ e-Sword, Strong s.v "phaneros"

${ }^{40}$ Hasan Sutanto, Perjanjian Baru Interlinear Yunani-Indonesia dan Konkordansi Perjanjian Baru jilid II, (Jakarta:Lembaga Alkitab Indonesia, 2003) jilid II 786

${ }^{41}$ Th. Van den End, Tafsiran Alkitab Surat Roma (Jakarta: BPK.Gunung Mulia, 1995) 124
} 
dalam bahasa Yunaninya menggunakan kata en sarki ( $\varepsilon v \sigma \alpha \rho \kappa \imath)$ dari kata sarx $(\sigma \alpha \rho \xi)$ dengan nomor strong G4561. Probably from the base of G4563 flesh (as stripped of the skin), that is, (strictly) the meat of an animal (as food), or (by extension) the body (as opposed to the soul (or spirit), or as the symbol of what is external, or as the means of kindred, or (by implication) human nature (with its frailties (physically or morally) and passions), or (specifically) a human being (as such): carnal (-ly, + -ly minded), flesh ([-ly])." ${ }^{42}$ Sarx $(\sigma \alpha \rho \xi)$ berarti "daging; tubuh; manusia (yang berdarah dan berdaging); tubuh (yang di dunia); tubuh (yang dikuasai dosa); jasmani". Analisa dari kata sarki ( $\sigma \alpha \rho \kappa \imath)$ ini ialah (Noun, Feminine, Singular, Dative)." ${ }^{43}$ Paulus memang seringkali memakai sarx, "daging", dalam arti yang sama sekali negatif, tetapi dalam hal itu yang dimaksud bukan badan secara khusus melainkan keadaan manusia secara umum. Sunat merupakan tanda di dalam badan dari perjanjian Allah dengan Israel."

Kata ketiga, "tidak nampak" dalam bahasa Yunaninya menggunakan kata krupto ( $\kappa \rho v \pi \tau \omega)$ dari kata kruptos dibaca kroop-tos ( $\kappa \rho v \pi \tau o \zeta)$ dengan nomor strong G2927. From G2928; concealed, that is, private: - hid (-den), inward [-1y], secret." Kruptos ( $\rho \rho \pi \tau o \zeta)$ berarti "yang tersembunyi, yang tidak kelihatan". Analisa dari kata krupto ( $\kappa \rho v \pi \tau \omega)$ ini ialah (Adjective, Neuter, Singgular, Dative, no degree)." ${ }^{46}$ Yang tersembunyi" atau "yang tidak nampak", yang ada di dalam hati merupakan ketaatan terhadap syarat-syarat perjanjian, yang tercantum di dalam hukum Taurat, keiklasan dalam melakukan hukum itu." ${ }^{, 7}$

Kata keempat, "di dalam hati" dalam bahasa Yunaninya menggunakan kata kardias ( $\kappa \alpha \rho \delta \imath \alpha \zeta)$ dari kata kardia dibaca kar-dee'-ah ( $\kappa \alpha \rho \delta i \alpha)$ dengan nomor strong G2588. Prolonged from a primary $\chi \alpha \rho$ (Latin cor, "heart"); the heart, that is, (figuratively) the thoughts or feelings (mind); also (by analogy) the middle: - (+

\footnotetext{
42 e-Sword, Strong s.v "sarx"

${ }^{43}$ Hasan Sutanto, Perjanjian Baru Interlinear Yunani-Indonesia dan Konkordansi Perjanjian Baru jilid II, (Jakarta:Lembaga Alkitab Indonesia, 2003) jilid II 699

${ }^{44}$ Th. Van den End, Tafsiran Alkitab Surat Roma (Jakarta: BPK.Gunung Mulia, 1995) 124

45 e-Sword, Strong s.v "kruptos"

${ }^{46}$ Hasan Sutanto, Perjanjian Baru Interlinear Yunani-Indonesia dan Konkordansi Perjanjian Baru jilid II, (Jakarta:Lembaga Alkitab Indonesia, 2003) jilid II 465

${ }^{47}$ Th. Van den End, Tafsiran Alkitab Surat Roma (Jakarta: BPK.Gunung Mulia, 1995) 124
} 
broken-) heart (-ed)." ${ }^{48}$ Kardia $(\kappa \alpha \rho \delta \boldsymbol{\delta} \alpha)$ berarti "hati, pusat". Analisa dari kata kardias ( $\kappa \alpha \rho \delta \boldsymbol{s} \alpha \zeta$ ) ini ialah (Noun, Feminine, Singgular, Genetive)". ${ }^{4}$

Kata kelima, "secara rohani" dalam bahasa Yunaninya menggunakan kata pneumati $(\pi v \varepsilon v \mu \alpha \tau \imath)$ dari kata pneuma dibaca pnyoo'-mah $(\pi v \varepsilon v \mu \alpha)$ dengan nomor strong G4151. From G4154; a current of air, that is, breath (blast) or a breeze; by analogy or figuratively a spirit, that is, (human) the rational soul, (by implication) vital principle, mental disposition, etc., or (superhuman) an angel, daemon, or (divine) God, Christ's spirit, the Holy spirit: - ghost, life, spirit (-ual, -ually), mind. Compare G5590." ${ }^{50}$ Pneuma ( $\left.\pi v \varepsilon v \mu \alpha\right)$ berarti "nafas, angin, roh. Roh, sikap". Analisa dari kata pneumati $(\pi v \varepsilon v \mu \alpha \tau \imath)$ ini ialah (Noun, Neuter, Singular, Dative)., ${ }^{51}$

Lembaga Alkitab Indonesia (LAI) menggunakan kata "secara rohani" dapat menyesatkan, sebab secara rohani dapat dipandang sebagai acuan pada tingkat atau lingkungan yang lebih tinggi, sesuai dengan pasangan kata "rohani-badani" dalam kosakata Indonesia. "sunat di dalam Roh" berarti: sunat seperti yang diterima manusia yang berada dalam lingkungan kuasa Roh. Maka tambahan "di dalam Roh" sesudah "sunat hati" menunjukan bahwa sunat itu, yaitu keihklasan hati, dikaruniakan oleh $\operatorname{Roh}^{52}$.

Kata keenam, "bukan secara hurufiah" dalam bahasa Yunaninya mengunakan kata grammati ( $\rho \alpha \mu \mu \alpha \tau)$ dari kata gramma dibaca gram'-mah $(\gamma \rho \propto \mu \mu \alpha)$ dengan nomor strong Gl121. From Gl125; a writing, that is, a letter, note, epistle, book, etc.; plural learning: - bill, learning, letter, scripture, writing, written."53 Gramma ( $\rho \alpha \mu \mu \alpha)$ berarti "huruf, tulisan, kitab, surat, ilmu". Analisa dari kata grammati ( $\rho \alpha \mu \mu \alpha \tau)$ ini ialah (Noun, Neuter, Singular, Dative.". "Sunat didalam huruf" berarti: sunat sebagaimana berfungsi

\footnotetext{
48 e-Sword, Strong s.v "kardia"

${ }^{49}$ Hasan Sutanto, Perjanjian Baru Interlinear Yunani-Indonesia dan Konkordansi Perjanjian Baru jilid II, (Jakarta:Lembaga Alkitab Indonesia, 2003) jilid II 427

50 e-Sword, Strong s.v "pneuma"

${ }^{51}$ Hasan Sutanto, Perjanjian Baru Interlinear Yunani-Indonesia dan Konkordansi Perjanjian Baru jilid II, (Jakarta:Lembaga Alkitab Indonesia, 2003) jilid II 651

${ }^{52}$ Th. Van den End, Tafsiran Alkitab Surat Roma (Jakarta: BPK.Gunung Mulia, 1995) $124-125$

53 e-Sword, Strong s.v "gramma"

${ }^{54}$ Hasan Sutanto, Perjanjian Baru Interlinear Yunani-Indonesia dan Konkordansi Perjanjian Baru jilid II, (Jakarta:Lembaga Alkitab Indonesia, 2003) jilid II 172
} 
dalam lingkungan "hukum tertulis" yang memang merupakan tanda perjanjian Tuhan dengan umat-Nya, namun tidak disertai ketaatan hati", ${ }^{55}$

Asumsi R.A. Jaffray dari penalarannya tentang ayat ini berkata: "dalam hal itu, rasul Paulus menasehatkan bahwa sesuatu yang termasuk dalam urusan lahir, takluk di bawah urusan rohani. Dengan demikian, orang Yahudi yang disunat karena aturan, tidak dapat disebut Yahudi secara rohani. Namun, mereka yang bersunat batinlah yang patut disebut Yahudi yang sejati., ${ }^{56}$

Keadaan ini menjelaskan bahwa "arti kata sunat" itu jangan ditekankan pada arti lahiriahnya, tetapi arti rohaniahnya saja yang diambil. Dengan demikian, "sunat hati" sesungguhnya lebih utama daripada "sunat tubuh" 57 Kebenaran tersebut sejajar dengan kebenaran Firman Tuhan dalam Perjanjian Lama menurut Ulangan 30:6 yang berbunyi demikian: "Dan TUHAN, Allahmu, akan menyunat hatimu dan hati keturunanmu, sehingga engkau mengasihi TUHAN, Allahmu, dengan segenap hatimu dan dengan segenap jiwamu, supaya engkau hidup".

Van den End menjelaskan bahwa Paulus menggambarkan situasi yang nyata di dalam ayat 28-29. Yang mana, orang Yahudi sejati ialah mereka yang melakukan hukum Taurat, yang menyimpan hukum Taurat dalam batin, menyunatkan hatinya; yang dijiwai bukan oleh hukum tertulis melainkan oleh Roh. Perlu diperhatikan bahwa sunat pada badan tidak menjamin orang tersebut masuk pada golongan ini. Sama seperti hukum Taurat, sunat barulah bermakna bila sifat-sifat tersebut terdapat dalam hati orang-orang yang bersangkutan." ${ }^{58}$ Bertolak dari pandangan di atas, menurut van der Linde bahwa keyahudian dan sunat bukanlah soal yang bertalian dengan kebangsaan dan kelahiran, bukan soal yang dapat dilihat dari luar. Keyahudian sejati tidak menonjolkan haknya yang istimewa, sebab ia tahu bahwa sunat yang sejati adalah soal hati yang merupakan karunia Allah., ${ }^{59}$

Jadi penulis dapat simpulkan bahwa sunat yang dilakukan secara lahiriah Sarx $(\sigma \alpha \rho \xi)$ yakni pada tubuh atau daging hanya sebatas aturan, tradisi atau sunat didalam huruf. Yang mana sunat berfungsi dalam lingkungan "hukum tertulis" atau Gramma ( үр $\mu \mu \alpha)$. Sedangkan Yahudi sejati ialah yang tersembunyi" atau "yang tidak nampak" keyahudiannya

${ }^{55}$ Th. Van den End, Tafsiran Alkitab Surat Roma (Jakarta: BPK.Gunung Mulia, 1995)

${ }^{56}$ R.A. Jaffray, Tafsiran Surat Roma (Bandung: Kalam Hidup, 2007) 47

${ }^{57}$ Ibid

${ }^{58}$ Th. Van den End, Tafsiran Alkitab Surat Roma (Jakarta: BPK.Gunung Mulia, 1995) $125-126$

${ }^{59}$ S. van der Linde, Surat Kiriman Kepada Orang Roma (Jakarta: BPK, 1966) 37 
Kruptos ( $\kappa \rho v \pi \tau o \zeta)$, dimana orang tersebut mau hidup dalam ketaatan terhadap syarat-syarat perjanjian, yang tercantum di dalam hukum Taurat, keiklasan dalam melakukan dan menghidupi hukum Taurat itu. Keyahudian sejati ialah menyediakan hati Kardia $(\kappa \alpha \rho \delta i \alpha)$ sebagai pusat atau sentral, yang mana manusia tersebut berada dalam lingkungan kuasa Roh yang dikaruniakan-Nya.

Roma 3:1 "Jika demikian, apakah kelebihan orang Yahudi dan apakah gunanya sunat?". Kata "kelebihan" dalam bahasa Yunaninya menggunakan kata perisson $(\pi \varepsilon \rho \imath \sigma \sigma o v)$ dari kata dasar Perissos dibaca per-is-sos' ( $\pi \varepsilon \rho i \sigma \sigma o \zeta$ ) dengan nomor strong G4053. From G4012 (in the sense of beyond); superabundant (in quantity) or superior (in quality); by implication excessive; adverb (with G1537) violently; neuter (as noun) preeminence: - exceeding abundantly above, more abundantly, advantage, exceedingly, very highly, beyond measure, more, superfluous, vehement [-ly]." Perissos ( $\pi \varepsilon \rho \imath \sigma \sigma o \zeta)$ berarti "yang lebih, istimewa, yang berlimpah-limpah, yang berlebih, yang tidak perlu". Analisa dari kata perisson $(\pi \varepsilon \rho \iota \sigma \sigma o v)$ ini ialah (Adjective, Neuter, Singgular, Nominative, no degree)." ${ }^{, 1}$

Dari pasal 3:1 ini R.A. Jaffray menjelaskan: "Rasul Paulus memulai Roma 3 dengan membuat pertanyaan dan menjawabnya sendiri. Paulus bertanya, "Apakah kelebihan orang Yahudi dan apakah gunanya sunat?" Ia menjawab banyak, dan yang pertama adalah karena Firman Tuhan dipercayakan kepada mereka. Dengan demikian mereka harus kukuh dan setia kepada Tuhan serta mengutamakan kebenaran atau ketulusan karena Tuhan pun tidak mengubah setia-Nya kepada mereka." ${ }^{2}$

Sedangkan van den End menjelaskan, bahwa ayat ini menghubungkan pasal 2:25-29. Menurut van den End, bahwa kalau memang terbukti hukum Taurat dan sunat, yang menandai kedudukan istimewa bangsa Yahudi sebagai bangsa terpilih, maka keadaan ini tidak dapat mencegah untuk bangsa ini dapat berdosa dan kena hukuman Allah. Jadi apa artinya kedudukan istimewa itu lagi? Apa makna pilihan Allah tersebut bagi mereka?" 63

Bangsa Israel menganggap diri mereka istimewa di hadapan Allah sebab mereka bersunat dan menjalankan hukum Taurat. Kata Perissos $(\pi \varepsilon \rho \imath \sigma \sigma o \zeta)$, yang bermakna "yang lebih; istimewa; yang berlebih"

\footnotetext{
60 e-Sword, Strong s.v "perissos"

${ }^{61}$ Hasan Sutanto, Perjanjian Baru Interlinear Yunani-Indonesia dan Konkordansi Perjanjian Baru jilid II, (Jakarta:Lembaga Alkitab Indonesia, 2003) jilid II 633

${ }^{62}$ R.A. Jaffray, Tafsiran Surat Roma (Bandung: Kalam Hidup, 2007) 49

${ }^{63}$ Th. Van den End, Tafsiran Alkitab Surat Roma (Jakarta: BPK.Gunung Mulia, 1995) 
merupakan kata sifat sebagi predikat, dimana derajat atau gelar lebih tinggi atau lebih besar. Pernyataan ini benar, sebab sunat dan hukum Taurat menjadikan mereka ekslusif dan istimewa di hadapan Tuhan, hal penting lainnya yang perlu diingat bahwa Firman Tuhan dipercayakan kepada mereka, merekalah yang menerima janji tersebut. Paulus kembali memperjelas kedudukan khusus bangsa Israel dengan bangsa-bangsa yang diluar Israel. Menurut Dave Hagelberg bahwa Paulus sudah menyampaikan seluruh pemahamannya yang benar bahwa hukum Taurat dan sunat hanya berguna bagi orang yang menaati Taurat saja. Sedangkan kedudukan orang Yahudi dan bukan Yahudi sama di pemandangan Tuhan." ${ }^{64}$

Pada bagian akhir, Paulus menampakan makna atau arti yang sesungguhnya tentang kekhususan tersebut. Paulus juga memposisikan dirinya bukan sebagai musuh atau lawan dari bangsa Yahudi dan bukan menjadi kawan atau sekutu terhadap bangsa kafir atau yang non Yahudi, melainkan dia berdiri ditengah sebagai seorang penegak kebenaran.

Dengan demikian bangsa itu tidak boleh bermegah atasnya, artinya menganggapnya sebagai bukti bahwa Allah berada di pihaknya dan bukan berada di pihak orang kafir. Seluruh dunia jatuh ke bawah hukuman Allah, termasuk bangsa Yahudi, tetapi karena itu juga seluruh dunia termasuk bangsa Yahudi, diselamatkan dengan cara yang sama, yaitu oleh iman. Hanya hukum iman itu tidak meniadakan hukum Taurat melainkan meneguhkannya ${ }^{65}$.

Ayat-ayat dibawah ini menurut penulis sebagai apologet Paulus atas perdebatan yang terjadi pada ayat-ayat sebelumnya. Yaitu pada pasal 3:2731:

Jika demikian, apakah dasarnya untuk bermegah? Tidak ada! Berdasarkan apa? Berdasarkan perbuatan? Tidak, melainkan berdasarkan iman! Karena kami yakin, bahwa manusia dibenarkan karena iman, dan bukan karena ia melakukan hukum Taurat. Atau adakah Allah hanya Allah orang Yahudi saja? Bukankah Ia juga adalah Allah bangsa-bangsa lain? Ya, benar. Ia juga adalah Allah bangsabangsa lain! Artinya, kalau ada satu Allah, yang akan membenarkan baik orang-orang bersunat karena iman, maupun orang-orang tak bersunat juga karena iman. Jika demikian, adakah kami membatalkan hukum Taurat karena iman? Sama sekali tidak! Sebaliknya, kami meneguhkannya.

\footnotetext{
${ }^{64}$ Dave Hagelberg, Tafsiran Roma dari bahasa Yunani, (Bandung: Kalam Hidup, 2004)

${ }^{65}$ Th. Van den End, Tafsiran Alkitab Surat Roma (Jakarta: BPK.Gunung Mulia, 1995) 
Sehingga pada bagian terakhir ini dapat disimpulkan, meskipun orang Yahudi menjadikan sunat dan hukum Taurat sesuatu yang dapat dibanggakan dan dilebih-lebihkan, yang menjadikan mereka ekslusif dan spesial di hadapan Tuhan, tetapi semuanya itu tidak menjamin mereka untuk diselamatkan dan terlepas dari dosa. Hanya Iman kepada Yesus Kristuslah yang dapat menyelamatkan mereka.

\section{Evaluasi}

Kekuatan dan Kelemahan

dari Para Penafsir Tentang Teologi Sunat

Pertama, R.A. Jaffray seorang Injili yang menganut teologi terapan atau practical teology. Dalam membahas teologi sunat dalam surat Roma 2:25-29; 3:1 cenderung lebih menekankan pada teologi terapan. Penulis menemukan banyak pemikiran-pemikirannya yang membahas teologi ini lebih kepada penerapan sehari-hari. Sebagai contoh, dapat di lihat pada halaman 43, mengenai penalaran R.A Jaffray terhadap Roma 2:27. Hal lain yang mana, pemakaian bahasa dalam pengkalimatan yang sederhana dan mudah dipahami oleh orang intelektual maupun kaum awam. Sedangkan yang menjadi kelemahan isi buku ini ialah, penggalian Alkitab tentang teologi sunat yang kurang begitu mendalam. Pembaca yang membaca isi buku ini tidak di puaskan dengan hasil yang di sajikan tentang teologi tersebut.

Kedua, van den End seorang teolog klasik, menginterpretasi teologi sunat dalam surat Roma 2:25-29; 3:1 dari sudut pandang Biblical teology dan Historical teology. Sebagian besar pemikiran van den End difokusan pada penggalian isi Alkitab dengan cara, analisa bahasa asli Alkitab serta dari sudut pandang sejarah Perjanjian Lama, yang di- komparasikan dengan teologi Perjanjian Baru. Sebagai contoh, dapat di lihat pada halaman 4l, mengenai penalaran van den End terhadap Roma 2:26. Komentarkomentarnya bersifat praktis yang disajikan dalam bentuk uraian teologis. Pembaca dipuaskan dengan pokok bahasan mengenai teologi sunat yang disajikan. Sedangkan yang menjadi kelemahan isi buku ini ialah kurangnya aplikasi atau penerapan dari penafsiran tersebut.

\section{Depenulisan Sunat Hati}

Sunat sebagai sebuah lambang Perjanjian yang di teguhkan Allah kepada Abraham dan keturunannya (Kej 17:9-14). Ikatan yang dibuat Allah dengan Abraham ini bersifat turun-temurun, maksudnya sunat perlu diwariskan kepada keturunan atau generasi selanjutnya. Hal ini dapat dilihat dan di temukan dalam tradisi Yahudi, bahwa sunat sampai saat ini masih dijalankan sebagai sebuah aturan yang penting dalam kebudayaan Yahudi. Seorang anak laki-laki Yahudi sesuai dengan hukum Taurat Musa, perlu di kuduskan bagi Allah tepat pada usia delapan hari harus disunat. 
Dalam Perjanjian Baru setiap orang dari kalangan non Yahudi yang takut akan Allah (Kis 10:2, 22; 13:16, 26) atau lebih dikenal dengan proselit ingin mengintegrasikan diri ke dalam kebudayaan dan agama Yahudi, itu sebabnya mereka menyunatkan dirinya untuk mengesahkan keyahudiannya. Tindakan ini sangat jelas bahwa sunat merupakan lambang Perjanjian yang lambat laun menjadi sebuah simbolis yang tidak bermakna. "Sunat lahiriah" merupakan sebuah kalimat yang tepat dalam mendepenulisankan keadaan orang Yahudi yang menjadikan sunat hanya sebagai sebuah tradisi Yahudi. Sunat lahiriah melambangkan keadaan seorang yang hidup dalam dosa. Itu sebabnya Yeremia berkata dalam Yeremia 4:4; 6:10, bahwa "Telinga mereka tidak bersunat dan tidak mendengar. Firman Tuhan menjadi cemooh bagi mereka." Kesukaannya yaitu hidup dalam dosa, tidak mempraktekkan dan menghidupi Firman Tuhan.

Paulus dalam tulisannya yang ditujukan kepada jemaat Roma berkata: "sunat memang ada gunanya, jika engkau menaati hukum Taurat, tetapi jika engkau melanggar hukum Taurat, maka sunatmu tidak ada lagi gunanya" (Roma 2:25). "Rasul Paulus membuktikan bahwa peraturan sunat, yang merupakan meterai itu tidak berguna jika tidak diikuti oleh kebenaran pribadi. Sunat yang sejati adalah sunat yang di dalam hati." ${ }^{66}$ Sunat memiliki makna yang cukup dalam, saat seorang mau taat pada hukum Taurat. Itu sebabnya muncul istilah "sunat hati". Sebagian besar teologi Paulus dalam Perjanjian Baru lebih menekankan pada sunat hati, mengerat kulit khatan hati.

Apa yang dimaksud dengan sunat hati? W. Steven Christian berkata: "kita harus mengerat kulit khatan hati kita untuk menjalin intimasi dengan Allah yang kudus. Hati yang tidak bersunat diperhitungkan sebagai kejahatan yang akan menyulut murka Allah. Mereka dimurkai dan ditolak karena tidak memberikan dirinya untuk dipotong kulit khatan hatinya." ${ }^{\circ 6}$ Sedangkan menurut David Ibrahim, sunat hati ialah penanggalan hidup yang lama serta menaati hukum-hukum Allah. Sebagai pelaku Firman Allah, bukan hal-hal jasmani yang ditonjolkan, melainkan perkara-perkara rohani." 68

Jadi menurut hemat penulis "sunat hati" ialah sebuah keadaaan di mana seseorang yang sebelumnya hidup dalam dosa namun saat dia sadar akan setiap pelanggaran tersebut, maka dia mempersilahkan Allah untuk masuk dalam hidupnya, membersihkan hatinya dari semua dosa atau mengerat kulit khatan hati (menyunatkan hatinya) serta menanggalkan

${ }^{66}$ G. Raymond Carlson, Surat Roma (Malang: Gandum Mas, 1978) 27

${ }^{67}$ W. Steven Christian, Kulit khatan (Jogyakarta: Andi, 2009) 77

${ }^{68}$ David Ibrahim, Pelajaran Surat 1 Korintus (Jakarta Barat: Mimery Press, 1999) 109 
hidup yang lama bagi Allah, sehingga dapat menjalin intimasi dengan Allah yang kudus. Dalam I Petrus l:16 Firman Tuhan berkata: "Kuduslah kamu, sebab Aku kudus". Hidup yang ditrasformasi Allah ialah hidup yang mau di bersihkan hatinya dari dosa atau disunat hatinya.

Pertanyaan seperti ini sering kali penulis dengar: "apakah kita perlu disunat (jasmani)? Orang Kristen tidak perlu disunat! Sunat itu hanya berlaku bagi Agama Islam, sedangkan agama Kristen tidak perlu?" Jawaban dari pertanyaan-pertanyaan ini merupakan opini dari teologi penulis, yaitu:

Pertama, orang percaya perlu disunat, sebab sangat bermanfaat bagi kesehatan. Allah membuka wawasan para medis tentang pentingnya sunat bagi manusia (alasan medis). Sunat memang tidak dibuat, karena alasan medis, tetapi sangat berarti secara medis." ${ }^{69}$

Kedua, orang percaya perlu disunat selain sebagai alasan kesehatan (medis) juga sebagai sarana penginjilan dalam mengkontekstualisasikan diri di sebuah komunitas dalam bermasyarakat, khususnya di kalangan muslim, dengan catatan jangan menjadikan sunat layaknya sebuah ritual atau kewajiban sama seperti agama Islam. Sebagai contoh, kehidupan Timotius dalam mengkontekstualisasikan diri dalam pelayanannya di antara orang Yahudi (Kis 16:1-4).

Ketiga, ada anggapan orang Kristen tidak perlu disunat! Sunat itu hanya berlaku bagi agama Islam, merupakan argument yang patut dipertimbangkan kembali, sebab orang Kristen pun perlu disunat. Kalau sunat sebagai sarana penginjilan atau mengkontekstualisasikan diri di tengah orang Islam mengapa tidak. Sebab alasan medis pun mendukung seseorang untuk disunat. Namun penulisan dalam karya ilmah ini lebih menekankan pada sunat hati atau mengerat kulit khatan hati. Seorang yang takut Tuhan, ialah seseorang yang mengerat atau menyunatkan hatinya dari dosa.

\section{Implementasi Sunat Bagi Kehidupan Kristen Masa Kini}

Prinsip-prinsip sunat yang perlu di terapkan dalam kehidupan Kristen masa kini berdasarkan Roma 2:25-29; 3:1 ialah: Pertama: sunat hati sebagai sarana intimasi manusia dengan Allah (I Pet 1:16), merupakan sebuah tindakan yang wajib bagi setiap orang-orang percaya. Kedua: pertobatan sejati ialah sebagai jalan masuk Roh Allah untuk mengerat, memotong atau membersihkan kulit khatan hati manusia dari segala dosa. Ketiga: sunat hati sebagai wujud dari transformasi yang Allah lakukan dalam kehidupan orang percaya. Yang mana tabiat lamanya di kerat, di potong atau di bersihkan, sehingga orang tersebut menjadi ciptaan baru dalam Kristus. Keempat: jangan menjadikan sunat sebagai simbol

${ }^{69}$ Ibid 51 
keselamatan layaknya baptisan. Sebab sunat maupun baptisan tidak membawa manusia pada keselamatan. Hanya iman kepada Kristuslah yang membawa seseorang kepada keselamatan (Ibrani 11:6a). Kelima: kekuatiran praktek sunat, membuat seseorang menjadi sama dengan agama lain. Itu sebabnya perlu memahami esensi sunat yang di ajarkan Paulus. Keenam: setelah menjelaskan prinsip-prinsip sunat pada awal bab II, mengapa tidak, seorang Kristen yang sudah mengetahui kebenaran; mempraktekan sunat dalam hidupnya, toh tindakan ini sangat bermanfaat dalam hidupnya (pandangan penulis dari segi medis) dengan merujuk pada pertimbangan dan alasan kesehatan.

\section{PENUTUP}

\section{Kesimpulan}

Pertama, sunat lahiriah tidak berfaedah ketika seseorang masih hidup dalam dosa dan tidak menaati Firman Tuhan. Kedua, sunat lahiriah hanya sebatas simbolis, sedangkan sunat hati sangat perlu dalam hidup kekristenan. Ketiga, Sunat yang dilakukan secara lahiriah ( $\operatorname{sarx} / \sigma \alpha \rho \xi)$ yakni pada tubuh atau daging hanya sebatas aturan atau tradisi. Keempat, sunat hati ialah sebuah situasi di mana seseorang yang sebelumnya hidup dalam dosa namun atas dasar kesadaran akan dosa atau pelanggaran, mempersilahkan Allah untuk masuk dalam hatinya, membersihkan hidupnya dari segala dosa (mengerat/menyunatkan hatinya) bagi Allah sehingga dapat menjalin intimasi dengan Allah yang kudus. Kelima, sunat sangat bermanfaat bagi kesehatan. Tuhan memakai para tenaga medis untuk menyingkapkan kebenaran. Allah tidak merancang sunat sebagai alasan medis, tetapi sunat sangat bermanfaat secara medis.

\section{Saran-Saran}

Dengan meninjau kembali pengajaran dan doktrin Paulus tentang sunat memang ada banyak hal yang jauh berbeda dari praktika sunat saat ini. Oleh sebab itu, melalui karya ini, penulis memberikan beberapa saransaran sebagai berikut: Pertama, penulis menyarankan praktek sunat bagi setiap anak-anak Allah dengan pertimbangan, penginjilan dan kontekstualisasi Injil jika di perlukan. Kedua, manfaat sunat bila dilihat dari sudut pandang medis sangat besar manfaatnya, oleh sebab itu penulis merekomendasikan setiap orang-orang percaya yang telah memahami esensi sunat secara benar untuk mempraktekkannya, jika hal tersebut perlu bagi setiap pembaca (tanpa unsur paksaan). Ketiga, hamba-hamba Tuhan 
sebagai pemimpin gereja hendaknya menanamkan doktrin kebenaran yang Alkitabiah termasuk sunat (sunat lahiriah maupun sunat batiniah). Keempat, hal penting lainnya, penulis menyarankan agar setiap pembaca dapat hidup dalam pertobatan yakni meninggalkan tabiat lama (dosa) dan mau menyunatkan hatinya bagi Kristus.

\section{DAFTAR PUSTAKA}

(Jakarta:Lembaga Alkitab Indonesia, 2003) jilid II

Alkitab Penuntun Hidup Berkelimpahan Full Life Study Bible, (Malang: Gandum Mas dan Lembaga Alkitab Indonesia, 2008) 1832

Benyamin, Wawancara Oleh Penulis, Makassar, Sulawesi Selatan, 4 Mei 2010.

Dave Hagelberg, Tafsiran Roma dari bahasa Yunani, (Bandung: Kalam Hidup, 2004)

David Ibrahim, Pelajaran Surat 1 Korintus (Jakarta Barat: Mimery Press, 1999)

Deki, Wawancara Oleh Penulis, Makassar, Sulawesi Selatan, 5 Mei 2010.

e-Sword, Strong s.v "gramma"

G. Raymond Carlson, Surat Roma (Malang: Gandum Mas, 1978)

Hasan Sutanto, Perjanjian Baru Interlinear Yunani-Indonesia dan Konkordansi Perjanjian Baru jilid II, (Jakarta:Lembaga Alkitab Indonesia, 2003) jilid II

Hendrik, Wawancara Oleh Penulis, Makassar, Sulawesi Selatan, 5 Mei 2010.

Martin Luther dalam R.A. Jaffray, Tafsiran Surat Roma (Bandung: Kalam Hidup, 2007)

R.A. Jaffray, Tafsiran Surat Roma (Bandung: Kalam Hidup, 2007) 
S. van der Linde, Surat Kiriman Kepada Orang Roma (Jakarta: BPK, 1966)

Th. Van den End, Tafsiran Alkitab Surat Roma (Jakarta: BPK.Gunung Mulia, 1995)

W. Steven Chirstian, Kulit Khatan, (Jogyakarta: Andi 2009)

William Barclay, Pemahaman Alkitab Setiap Hari, Roma, (Kwitan, Jakarta: BPK.Gunung Mulia, 1986) 